\title{
Influence of Solar Energy on Encysted Parasitic Protozoa Giardia and Entamoeba spp in Water-Treatment Plants, Egypt
}

\author{
Azza Hassan Mohamed ${ }^{1}$, Mansour Galal ${ }^{1}$, Gamalat Y. Osman ${ }^{1}$ and Mohammed Aboamer ${ }^{2}$ \\ 1. Department of Zoology, Faculty of Science, Menoufiya University, Egypt \\ 2. Holding Company of Water \& Waste Water, Menoufiya, Egypt
}

Received: September 15, 2014 / Accepted: October 05, 2014 / Published: October 25, 2014.

\begin{abstract}
Polluted water with parasitic protozoa (Giardia lamblia and Entamoeba histolytica) causes many serious health problems like diarrhea and gastrointestinal diseases. The present study investigated the applicability of solar energy for disinfection of parasitic protozoa in polluted water. One-side blackened bottles of two liters volume each were continuously exposed to direct sun light for about seven hours which maintained water temperature in the range of $50-60{ }^{\circ} \mathrm{C}$ that was enough for destroying most of the encysted parasitic protozoa. Complete destruction of the encysted protozoa was achieved in both bottles facing south and those vertically in position at $60^{\circ} \mathrm{C}$ with an ambient temperature of $40^{\circ} \mathrm{C}$. The influence of water temperature against the viability of these two cysts was found to be highly significant $(\mathrm{P}<0.001)$ in both cases particularly those of Giardia where its regression coefficient equal -1.5 as compared to that of Entamoeba (-1.27). The low cost and operational simplicity of this study make it affordable and usable. It is more useful in rural areas where other sources of energy like electricity and gas are not easily available.
\end{abstract}

Key words: Solar energy, solar disinfection, decontamination water, Entamoeba and Giardia cysts.

\section{Introduction}

Egypt has limited water resources; it depends mainly on River Nile for the domestic, industrial and irrigation uses. The rapid increase in population and urbanization is a big challenge to the country in facing water scarcity [1]. Our health depends on having an adequate supply of safe water for drinking, cooking, laundry and bathing every day. If water becomes contaminated with different pollutants as microorganisms and chemicals, diseases spread out over the country and then gastrointestinal upset, diarrohea or even death occur [2, 3]. Also, waterborne outbreaks have economic consequences [4]. Interest in the contamination of drinking water by enteric pathogenic

Corresponding author: Azza Hassan Mohamed, doctor, professor and Mohammed Mahmoud Aboamer, research fields: immunology and parasitology. E-mail: Mohamed_aboamer2003@yahoo.com.
Protozoa has increased considerably during the past three decades and the waterborne route transmits a number of protozoan parasitic infections of humans [5]. Several species of parasitic Protozoa are transmitted through water; Giardia and Entamoeba are recognized as the most common intestinal parasites throughout the world, they produce cysts that withstand harsh environmental conditions, as arrest stage until its ingestion [6].

Chlorine, as a widely used disinfectant at water treatment plants, does not kill some parasitic protozoan cysts if its density and contact time with water are reduced $[7,8]$. Cysts are naturally electronegative, thus the physical removal of Giardia and Entamoeba cysts that occur by multiple barriers is very important at water treatment plants at both the coagulation and filtration stages of water treatment process where cyst 
and oocyst densities were reduced and water became safe to be used in drinking $[9,10]$.

Measuring of the physico-chemical parameters of water; such as temperature, electrical conductivity, total dissolved solids, $\mathrm{pH}$, phosphate, ammonia-nitrogen, total hardness, calcium, iron, manganese, chlorides, magnesium, nitrate and turbidity of the water is important to investigate both water quality and ecological variations of the water body [11]. One of the most important factors of water pollution is the microbial contaminations; especially with pathogenic microorganisms and enteric pathogens are typically responsible for waterborne illness [12]. Bacteriological water analysis is a method of analyzing water to estimate the numbers of bacteria present and find the sort of bacteria that contaminated the water source [13].

Solar Water Disinfection (SODIS) was a simple, environmentally sustainable, low-cost solution for drinking water treatment for people consuming microbiologically contaminated raw water. SODIS used solar energy to destroy some encysted parasitic Protozoa (Cryptosporidium, Cyclospora and Isospora) causing water borne diseases and improved the quality of drinking water. Cryptosporidium and Cyclospora were vulnerable to two effects of the sunlight: radiation and heat (increased water temperature). Contaminated distilled water was filled into transparent plastic bottles painted one side black and exposed to full sunlight for seven hours. During the exposure to the sun these encysted parasitic Protozoa were destroyed. When water temperatures exceed $50^{\circ} \mathrm{C}$, one hour of exposure was sufficient to obtain safe drinking water $[14,15]$. SODIS is a type of potable water purification using solar energy by removing its infectious biological agents such as bacteria, viruses, protozoa and worms. However, non-biological agents such as toxic chemicals or heavy metals were not influenced by disinfection. Consequently, additional steps beyond disinfection may be necessary to make water clean to drink. The effect of the radiation intensity, water turbidity and exposure time on the survival of Cryptosporidium parvum during simulated solar disinfection of drinking water indicated that radiation intensity and radiation intensity with exposure time between 8 and $12 \mathrm{~h}$ were required to reduce the oocyst infectivity in water samples with different degrees of turbidity [16]. SODIS is also considered as a type of treatment that can significantly improve the microbiological quality of drinking water at household level and therefore prevent waterborne diseases in developing countries. Cryptosporidium parvum is protozoan parasite that is responsible for the diarrhoeal disease cryptosporidiosis in humans and animals. Recently, this parasite has been selected by the WHO as a reference pathogen for protozoan parasites in the evaluation of household water treatment options. So that a research of comparison of different solar reactors for household disinfection of drinking water in developing countries with evaluation of their efficacy in relation to the waterborne enteropathogen such as Cryptosporidium parvum to be treated and become rendered totally unviable in water samples [17]. The present study aimed to use solar energy in order to evaluate its efficiency to destroy the encysted parasitic Protozoa (Giardia and Entamoeba) via its thermal effect and hence improves the quality of the drinking water. This was carried out by using bottles painted black on one side.

\section{Materials and Methods}

Samples were collected at different water treatment stages belonging to certain water treatment plants in Shebin Elkom, El-Menoufiya province. Polyethylene terephthalate (PET) containers were used in this study, one was painted with black color on one side, the second was nonpainted and the third one had an open at the top. Painting the container black on one side caused the increase in temperature.

One-side blacked bottles of two liters volume each were continuously exposed to direct sun light for about seven hours which maintained water temperature in the 
range of $50-60{ }^{\circ} \mathrm{C}$. Another set of bottles were painted one side black facing south beside those placed vertically in positions at $60{ }^{\circ} \mathrm{C}$ with an ambient temperature of $40^{\circ} \mathrm{C}$.

The initial temperature of the contents was measured, then temperatures were recorded hourly for $7 \mathrm{~h}$, with one PET container painted black on one side being taken hourly for viability test and the rest of the containers were analyzed after the $7 \mathrm{~h}$. One of the PET containers was a control, which was kept in the no direct sunlight for $7 \mathrm{~h}$, without being exposed to the sun. The biocidal potential of sun light was evaluated by comparing the viability and vitality of both encysted parasitic protozoa (Entamoeba and Giardia) that were collected at (10: $00 \mathrm{am}, 12: 00 \mathrm{pm}, 14: 00 \mathrm{pm}$ and 16:00 $\mathrm{pm})$.

The Viability assay for the encysted parasitic protozoa (Entamoeba and Giardia cysts) and the viability testing of cysts was performed before addition of these parasites to the test containers to ensure $100 \%$ viability of all cysts before testing. Water from the containers was put in $50 \mathrm{~mL}$ sample batches tubes and centrifuged at 1,500 rpm for $10 \mathrm{~min}$. The sediments were pooled to make one $1 \mathrm{~mL}$ suspension. Viability testing was performed by using $0.4 \%$ trypan blue stain.

One $\mathrm{ml}$ of the sediment of the samples was stained with the vital dye namely, $0.4 \%$ trypan blue, as described in Ref. [18], where viable cysts do not take up the dye. A haemocytometer or Sedgwick- Rafter cell was used to count the viable and nonviable cysts. The same assays were also run under no direct sun light conditions. These experiments were repeated 15 times and the average values and standard deviation were estimated for analysis.

\section{Results}

Solar water disinfection system (SODIS) using PET containers painted black on one side can be used to disinfect water against Giardia and Entamoeba spp and destroy their cysts as well. The obtained results showed that cysts of Giardia and Entamoeba rendered not infective after batch SODIS exposures of seven hours, and consequently solar energy could be considered as highly effective against waterborne parasitic protozoan diseases. Also these results demonstrated that SODIS is an appropriate household water treatment technology for use as an emergency against pathogenic protozoan cysts. These experiments were repeated several times and the average data were used for analysis as could be seen in (Table 1).

The results have been shown that using two liters PET bottles containing contaminated raw water with parasitic

Table 1 Influence of solar energy in killing parasitic protozoan cysts (Entamoeba and Giardia).

\begin{tabular}{llllll}
\hline Time intervals Temperature $\left({ }^{\circ} \mathrm{C}\right)$ & No. of Giardia cysts & \% viable Giardia Sp. & No. of Entamoeba cysts & \% viable Entamoeba Sp. \\
\hline $9: 00 \mathrm{am}$ & 25.7 & 57 & 100 & 48 & 100 \\
$9: 30 \mathrm{am}$ & 28.8 & 54 & 95 & 46 & 97 \\
$10: 00 \mathrm{am}$ & 31.8 & 52 & 92 & 43 & 90 \\
$10: 30 \mathrm{am}$ & 34.5 & 46 & 81 & 38 & 80 \\
$11: 00 \mathrm{am}$ & 40.38 & 45 & 80 & 38 & 80 \\
$11: 30 \mathrm{am}$ & 43.3 & 42 & 75 & 33 & 70 \\
$12: 00 \mathrm{pm}$ & 46.38 & 39 & 70 & 28 & 60 \\
$12: 30 \mathrm{pm}$ & 48.33 & 34 & 60 & 25 & 55 \\
$13: 00 \mathrm{pm}$ & 50.46 & 27 & 48 & 21 & 45 \\
$13: 30 \mathrm{pm}$ & 51.4 & 17 & 30 & 14 & 31 \\
$14: 00 \mathrm{pm}$ & 55.3 & 13 & 25 & 12 & 27 \\
$14: 30 \mathrm{pm}$ & 59.5 & 5 & 10 & 5 & 0 \\
$15: 00 \mathrm{pm}$ & 58.5 & 0 & 0 & 0 & 0 \\
$15: 30 \mathrm{pm}$ & 57.5 & 0 & 0 & 0 & 0 \\
$16: 00 \mathrm{pm}$ & 39.5 & 0 & 0 & 0 & 0 \\
$16: 30 \mathrm{pm}$ & 41.23 & 0 & 0 & & 0 \\
\hline
\end{tabular}


protozoan cysts with no direct sun light $\left(31.3^{\circ} \mathrm{C}\right)$, only $8 \%$ and $10 \%$ of Giardia, Entamoeba cysts, respectively were destroyed and become not infective. On the other hand, in case of two liters PET bottles, with direct sun light and no blackened side $\left(48.5^{\circ} \mathrm{C}\right)$ containing also contaminated raw water with cysts of parasitic protozoa (Giardia \& Entamoeba), the results showed that when the temperature raised to $48.5^{\circ} \mathrm{C}$, it was shown that only $30 \%$ of Giardia cysts were destroyed and rendered non infective, while $70 \%$ of these cysts were still viable, and in case of Entamoeba cysts only $25 \%$ were destroyed and non infective, while $75 \%$ of these cysts were still viable.

Simultaneously, exposing two liters PET bottles with direct sun light and one side black $\left(59.5{ }^{\circ} \mathrm{C}\right)$ containing naturally contaminated raw water with cysts of Giardia \& Entamoeba exhibited 95\% and 97\% of Giardia and Entamoeba cysts were destroyed and become non infective. These results were confirmed by using trypan blue as a vital stain that discriminates between viable and destroyed cysts where the viable cysts of Giardia \& Entamoeba didn't accept the stain, while destroyed and not infective cysts accepted the stain as shown in Fig. 1. Solar energy was tested for its capacity to disinfect water contaminated with Giardia and Entamoeba. There was a synergistic effect between sun and its thermal energy that caused cysts inactivation. Complete inactivation was attained at $59.5{ }^{\circ} \mathrm{C}$ after $7 \mathrm{~h}$ of sunlight exposure. Solar disinfection was then implemented in one of the communities in order to test its effectiveness. There was a reduction in the infection of the contaminated water with cysts of these parasitic Protozoa.

Viability assay for the encysted parasitic protozoa (Entamoeba and Giardia cysts).

The biocidal potential of sun light was evaluated by comparing the viability of both encysted parasitic protozoan; Entamoeba and Giardia cysts that collected at 10: $00 \mathrm{am}, 14: 00 \mathrm{pm}$ and 16:00 pm. The results of viability using Trypan blue stain showed total destruction (100\%) of the encysted Entamoeba cysts and Giardia cysts in one side blackened bottles exposed to direct sun light at the third group which have samples in direct sun light with one side black at (14:00 pm) and (4:30 pm) after seven hours of exposure. On the other hand, cysts of both Entamoeba and Giardia were viable in sample exposed to no direct sun light at all the various groups, while samples with direct sun light exposure and no blackened side recorded $40 \%$ viability at the second group which have samples in direct sun light exposure. And as indicated at this table of SODIS conditions after $7 \mathrm{~h}$ exposure to solar energy and viability of parasitic protozoa cysts (Giardia \& Entamoeba). The results showed that in case of no direct sunlight the temperature values did not exceeded $\left(31.3^{\circ} \mathrm{C}\right)$ and the viability of parasitic protozoa cysts were high (90\%-92\%), respectively. While in case of direct sunlight with no blackended side temperature values was $\left(48.5^{\circ} \mathrm{C}\right)$ and the viability of parasitic protozoa cysts were (70\%-75\%) respectively. Also in case of Direct sun light with one side black with temperature that may be exceeded $\left(59.5^{\circ} \mathrm{C}\right)$ it has the highly efficiency of destroying and killing of parasitic protozoa (Giardia and Entamoeba) cysts with viability (5\%-3\%) of those cysts, respectively.

\section{Discussion}

In the present study, the achieved results investigated the potential of using solar energy to disinfect, naturally, polluted raw water. Solar energy was used to destroy encysted parasitic protozoa (Giardia and Entamoeba) via its thermal and UV effect and hence improves the quality of drinking water. This was performed during June 2012. The maximal gained water temperature on a sunny day was found to be $60{ }^{\circ} \mathrm{C}$, corresponding to an ambient temperature of $40{ }^{\circ} \mathrm{C}$. These results are in agreement with [19] who used solar energy for deactivation of coliform bacteria.

Samples of naturally polluted raw water had been collected with Giardia and Entamoeba cysts that have been found to be extremely resistant to Solar Water 

Water-Treatment Plants, Egypt

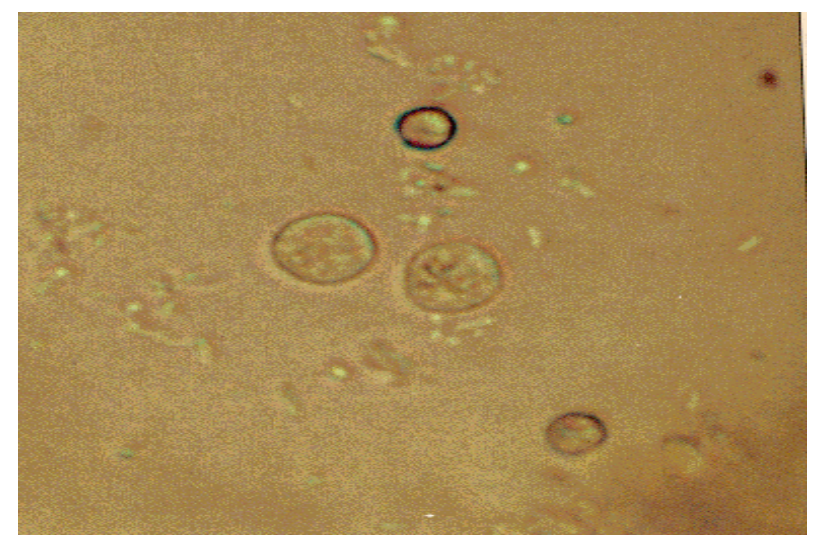

(a)

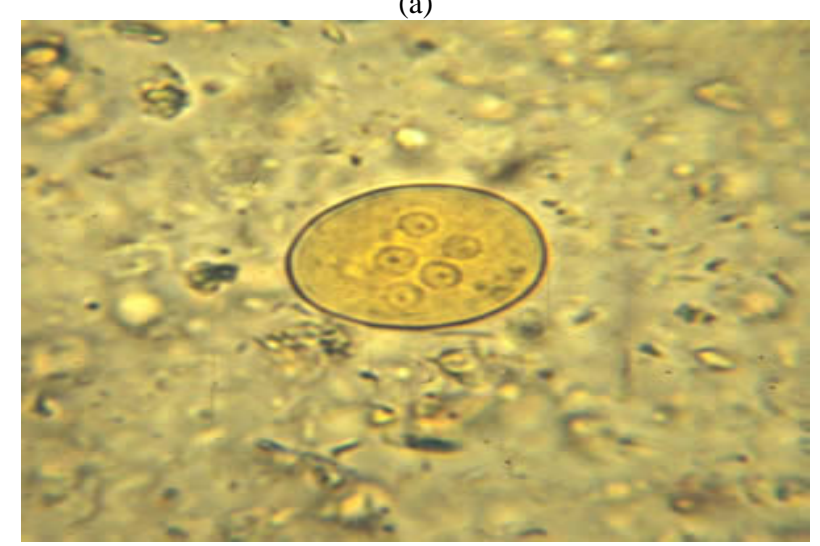

(b)

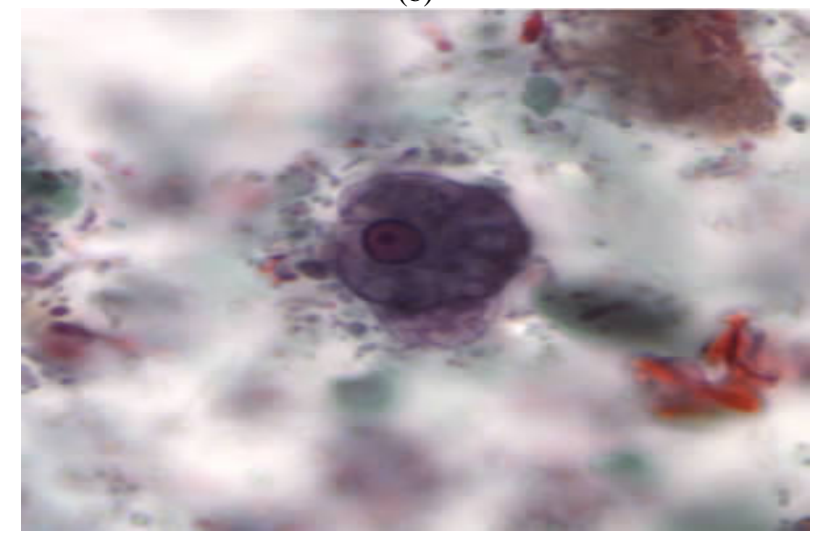

(c)

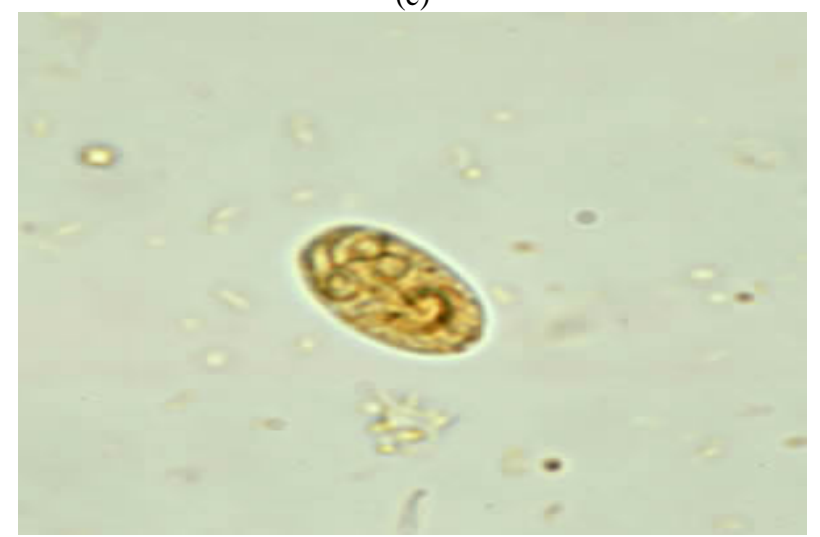

(d)

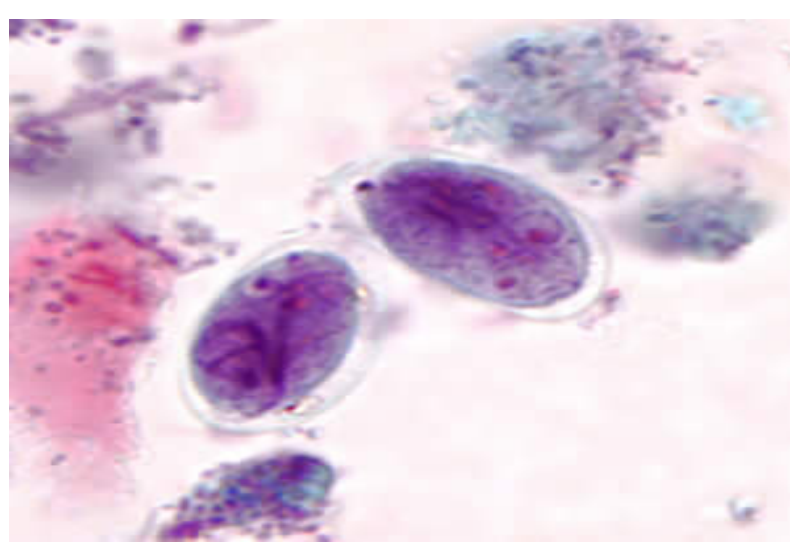

(e)

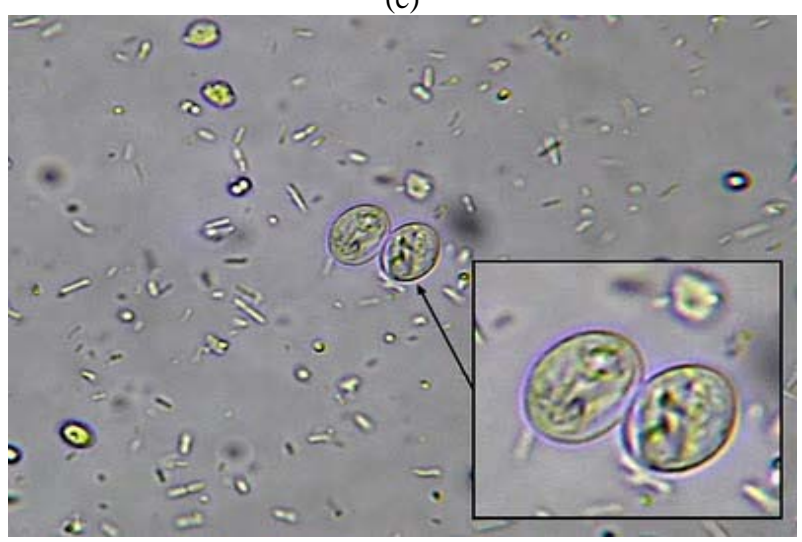

(f)

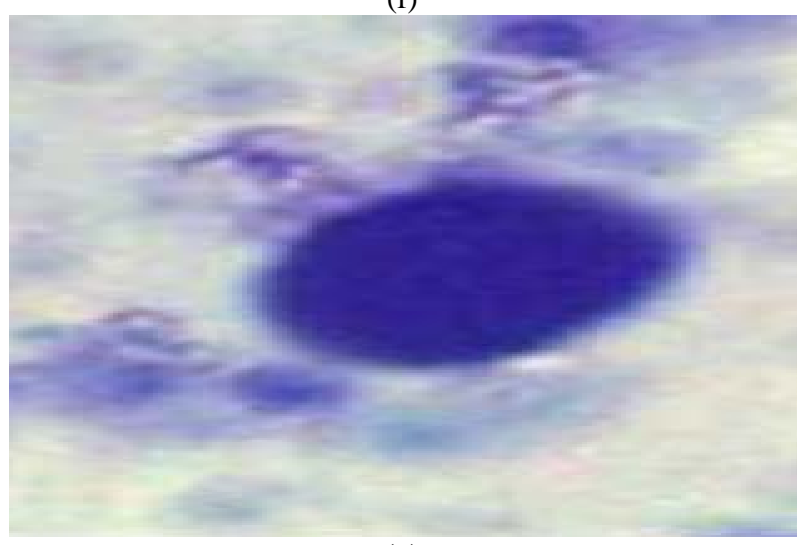

(g)

Fig. 1 Photomicrograph of (a) Entamoeba cysts in raw water samples stained with Iodine stain $(100 \times)$, (b) Entamoeba cyst in raw water samples stained with Iodine stain $(400 \times)$, (c) Entamoeba cyst in treated water samples stained with acid fast trichrome stain $(400 \times)$, (d) Giardia cyst in raw water samples stained with Iodine stain $(400 \times)$, (e) Giardia cysts in raw water samples stained with Acid fast trichrome stain $(400 \times)$, (f) Giardia cysts in raw water samples by phase contrast microscope $(400 \times)$ and (g) indicate dead Giardia cyst in raw water sample after exposure to direct sunlight for seven hours, stained with Trypan blue stain $(1,000 \times)$. 
Table 2 Mean values of temperature of raw water samples that contaminated with parasitic protozoa (Entamoeba and Giardia cysts) exposed to sunlight during June 2012.

\begin{tabular}{|c|c|c|c|}
\hline \multirow[b]{2}{*}{ Time Interval } & Group (1) & Group (2) & Group (3) \\
\hline & $\begin{array}{l}\text { Sample with No direct sun light. } \\
\text { Mean (min-max)** }\end{array}$ & $\begin{array}{l}\text { Sample with direct sun light } \\
\text { Mean (min-max) }\end{array}$ & $\begin{array}{l}\text { Sample with direct sun light with } \\
\text { one side black Mean (min-max) }\end{array}$ \\
\hline 10: $00 \mathrm{am}$ & $25.5^{\circ} \mathrm{C}(25-27)$ & $29.8^{\circ} \mathrm{C}(28-30)$ & $31.8^{\circ} \mathrm{C}(30-35)$ \\
\hline 10: $30 \mathrm{am}$ & $25^{\circ} \mathrm{C}(25-26)$ & $29.5^{\circ} \mathrm{C}(27-30)$ & $34.5^{\circ} \mathrm{C}(33-35)$ \\
\hline 11: $00 \mathrm{am}$ & $26.9^{\circ} \mathrm{C}(26.5-27.5)$ & $32.7^{\circ} \mathrm{C}(32-35)$ & $40.38^{\circ} \mathrm{C}(42-44)$ \\
\hline 11: $30 \mathrm{am}$ & $27.3^{\circ} \mathrm{C}(26-29)$ & $33.5^{\circ} \mathrm{C}(33-35)$ & $43.3^{\circ} \mathrm{C}(42-44)$ \\
\hline 12: $00 \mathrm{pm}$ & $28.4^{\circ} \mathrm{C}(26.5-30)$ & $38.62{ }^{\circ} \mathrm{C}(38-42)$ & $46.38^{\circ} \mathrm{C}(45-48)$ \\
\hline 12: $30 \mathrm{pm}$ & $30.3^{\circ} \mathrm{C}(30-32)$ & $40.5^{\circ} \mathrm{C}(40-42)$ & $48.33^{\circ} \mathrm{C}(48-49)$ \\
\hline $13.00 \mathrm{pm}$ & $31.23^{\circ} \mathrm{C}(31-32)$ & $45^{\circ} \mathrm{C}(45-45)$ & $50.46^{\circ} \mathrm{C}(50-51)$ \\
\hline 13: 30 pm & $29.5^{\circ} \mathrm{C}(30-31)$ & $45^{\circ} \mathrm{C}(45-45)$ & $51.4^{\circ} \mathrm{C}(50-53)$ \\
\hline 14: $00 \mathrm{pm}$ & $28.69^{\circ} \mathrm{C}(28.5-29)$ & $48.15^{\circ} \mathrm{C}(48-49)$ & $55.3^{\circ} \mathrm{C}(55-56)$ \\
\hline $14: 30 \mathrm{pm}$ & $28.5^{\circ} \mathrm{C}(28-28.5)$ & $48.5^{\circ} \mathrm{C}(46-47)$ & $59.5^{\circ} \mathrm{C}(57-61)$ \\
\hline $15: 00 \mathrm{pm}$ & $26.69^{\circ} \mathrm{C}(26-27)$ & $40.38^{\circ} \mathrm{C}(40-41)$ & $57.5^{\circ} \mathrm{C}(57-61)$ \\
\hline $15: 30$ pm & $25.5^{\circ} \mathrm{C}(26-26)$ & $39.5^{\circ} \mathrm{C}(41-46)$ & $29.5^{\circ} \mathrm{C}(46-48)$ \\
\hline $16: 00 \mathrm{pm}$ & $25.9^{\circ} \mathrm{C}(25-26.5)$ & $38.1^{\circ} \mathrm{C}(36-40)$ & $41.23^{\circ} \mathrm{C}(38-40)$ \\
\hline
\end{tabular}

** The data were expressed as mean and recorded from 15 consecutive days.

Table 3 SODIS conditions after 7 h exposure to solar energy and viability of parasitic protozoa cysts (Giardia \& Entamoeba).

\begin{tabular}{llll}
\hline $\begin{array}{l}\text { Types of containers } \\
\text { (Two liters PET bottles ) }\end{array}$ & Highest temperature attained $\left({ }^{\circ} \mathrm{C}\right)$ & $\%$ viable Giardia Sp. & \% viable Entamoeba Sp. \\
\hline No direct sun light & 31.3 & $92 \%$ & $90 \%$ \\
Direct sun light with no blackened side & 48.5 & $70 \%$ & $75 \%$ \\
Direct sun light with one side black & 59.5 & $5 \%$ & $3 \%$ \\
\hline
\end{tabular}

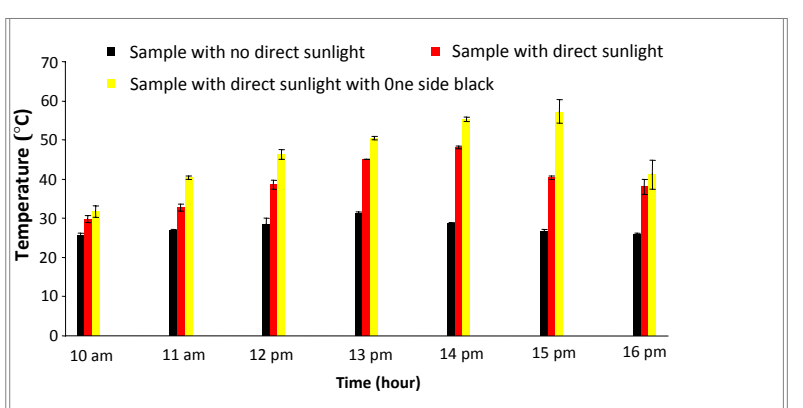

Fig. 2 Effect of sun light on temperature of raw water samples that contaminated with parasitic protozoa (Entamoeba and Giardia cysts) during June 2012.

Disinfection (SODIS) under normal conditions of sunlight and water temperature. Complete destruction of these cysts was achieved when water temperature raised above $56{ }^{\circ} \mathrm{C}$ using blackend bottles. These results are in agreement with [20] and [21] who demonstrated the impact of natural sunlight in disinfecting distilled water that contaminated with cysts of Giardia duodenalis and Entamoeba histolytica /dispar from stool samples that were collected from 100 rural school infected children using plastic PET (polyethylene terephthalate) containers.

In the present study elevated water temperatures are easily achievable in thermally PET (polyethylene terephthalate) blackened bottles. The present observations showed that exposures to only $7 \mathrm{~h}$ of sunlight produce a total destruction (100\%) complete destruction of encysted parasitic protozoan (Giardia and Entamoeba) cysts. Inactivation of the cysts can be accelerated by darkening the rear-sides and surfaces of the PET container or placing it in a sheltered location on a dark background. These results are supported by those of [22] and [23] who stated that batch solar disinfection (SODIS) can be used to inactivate oocysts of Cryptosporidium parvum and cysts of Giardia muris in experimentally contaminated distilled water.

In the present study, SODIS may produce damaged parasitic protozoan cysts (Giardia and Entamoeba) that are nonviable and incapable of producing an infection, which is consistent with the observations of other authors; [24-27]. These authors mentioned that the 
reduced infectivity of parasitic protozoan cysts (Giardia and Entamoeba) induced by incomplete solar radiation is not permanent, and DNA repair processes may start after exposure. However, these studies showed that DNA repair after thermal sunlight and sunlight UV exposure of cysts is not sufficient to allow them to recover infectivity and the damage in the membrane of the cysts wall as viewed in the present results of viability assay for the encysted Entamoeba and Giardia cysts. Trypan blue (0.4\%), confirmed this hypothesis and the present results concluded that a recovery in the cyst infectivity status is unlikely after SODIS disinfection.

The present data showed that the effect caused by sunlight may be due to both optical and thermal processes that occur at temperatures above $56{ }^{\circ} \mathrm{C}$ which is consistent with those of $[15,28]$.

The combined effect of temperatures of $50-60{ }^{\circ} \mathrm{C}$ and UV radiation most probably leads to inactivate and destroy cysts of Giardia \& Entamoeba spp. Evidence of this synergistic effect has been documented for vegetative bacteria, but it has not been studied for viruses [29].

These results are in agreement with $[16,17]$ who demonstrated that complete excystation of Cryptosporidium parvum oocyst occur at temperatures that are reached during using of simple solar water disinfection (SODIS).

It was found that in order to increase the absorption rate of heat, techniques such as painting the containers black on one side have to be employed. This agrees with the study of Ref. [30] that covered the rear surface of the solar disinfection container with aluminum foil improved the inactivation efficiency of the system. Also the current results consistent with the study of Ref. [31] who inactivated total coliforms and Escherichia coli in contaminated distilled water samples using PET bottles partially blackened on one side and others not blackened.

The achieved results indicated that comparison of Giardia and Entamoeba cysts in this study clearly indicates that loss of viability of the latter organism is slower as compared to the former. The low heat produced by PET bottles that were not painted containers also had decreased effect of loss of viability of Entamoeba cysts, and the present results are coincided with the results of Refs. [32] and [33] who suggested that about $10 \%$ of the world's populations are carriers of this particular organism, and these parasitic infections are prevalent in developing countries due to using of unsafe water.

Finally, it is possible to recommend that solar energy can be used mainly in developing countries due to its synergistic effect, to minimize or even prevent infectivity of certain parasitic protozoa and/or its cysts as a result of its cheapness and its permanent availability.

\section{Conclusions}

Solar energy and its thermal effect have a synergistic effect in killing cysts of Giardia and Entamoeba when temperature increases up to more than $50{ }^{\circ} \mathrm{C}$ with complete death at $60{ }^{\circ} \mathrm{C}$, using painted 2-L bottles containers painted black on one side. The potential effect of sun light was evaluated by comparing the viability of encysted parasitic protozoa (Entamoeba and Giardia) collected at 10: $00 \mathrm{am}, 14: 00 \mathrm{pm}$ and 16:00 pm of three groups. The results of viability using Trypan blue stain showed total destruction (100\%) of these encysted parasitic protozoa in the one sided black bottles exposed to direct sun light. On the other hand, encysted parasitic protozoa (Entamoeba and Giardia) were found to be alive totally in samples exposed to no direct sun light, while samples with direct sun light exposure recorded only $40 \%$ viability.

\section{References}

[1] H. El Gammal, Data Collection for Design of water and Wastewater Treatment Facilities, Report No. 43, Environmental Services for Improving Water Quality Management in Egypt, 2008.

[2] American Public Health Association (APHA) (1998): Standard Methods for Examination of Water and Wastewater, 20th ed., Washington, DC. 
[3] T.R. Slifko, H.V. Smith, J.B. Rose, Emerging parasite zoonoses associated with water and food, Int. J. Parasitol. 30 (2000) 1379-1393.

[4] S. Percival, R. Chalmers, M. Embrey, P. Hunter, J. Sellwood, P. Wyn-Jones, Microbiology of Waterborne Diseases, Oxford, Elsevier, 2004.

[5] P. Karanis, C. Kourenti, H. Smith, Waterborne transmission of protozoan parasites: A worldwide review of outbreaks and lessons learnt, J. Appl. Wat. Health 5 (2007) 1.

[6] L. Thriat, F. Sidaner, J. Schwartzbrod, Determination of Giardia cyst viability in environmental and faecal samples by immunofluorescence, fluorogenic dye staining and differential interference contrast microscopy, Lett. Appl. Microbiol. 70 (2004) 237-242 .

[7] P.M. Wallis, S.L. Erlandsen, J.L. Isaac-Renton, M.E. Olson, W.J. Robertson, H. van Keulen, Prevalence of Giardia cysts and Cryptosporidium oocysts \& characterization of Giardia species isolated from drinking water in Canada, Appl. Environ. Microbiol. 62 (1996) 2789-2797

[8] L. Liberti, M. Notarnicola, D. Petruzzelli, Advanced treatment of municipal wastewater reuse in agriculture, UV disinfection: Parasite removal and by-product formation, Desalination 152 (2002) 315-324.

[9] S. Capizzi-Banas, M. Maux, J. Schwartzbrod, Surface hydrophobicity of Ascaris eggs and Giardia cysts, Helminthologia 39 (2002) 197-204.

[10] W.Q. Betancourt, J.B. Rose,: Drinking water treatment processes for removal of Cryptosporidium and Giardia, Vet. Parasitol. 126 (2004) 219-234

[11] World Health Organization (WHO): Guidelines for Drinking-Water Quality, Vol. 2, 2nd ed., Geneva, 1996, pp. 100-117.

[12] Karaboze, F. Ucar, R. Eltem, G. Ozdmir, M. Ates, Determination of existence and count of pathogenic microorganisms in Izmir Bay, J.E.S 26 (2003) 1-18.

[13] S.Z. Sabae, S.A. Rabeh, Evaluation of the microbial quality of the River Nile water at Damietta branch, Egypt, Egy. J. Aquat. Res. 33 (2007) 301-311.

[14] F. Razzak, A. Haddaad, N. Ayoob,Y. Nakeya, Utilization of Solar energy in liquid milk processing, Magallat Buhut Al-Taqat Al-Samaiyyat 3 (2) (1985) 35-39.

[15] K.G. McGuigan, F. Mendez-Hermida, J.A. Castro-Hermida, E. Ares-Mazas, S.C. Kehoe, M. Boyle, et al., Batch solar disinfection inactivates oocysts of Cryptosporidium Parvum and cysts of Giardia muris in drinking water, J. Appl. Microbiol. 101 (2006) 453-463.

[16] H. Gómez-Couso, M. Fontán- Sainz, K.G. McGuigan, E. Ares-Mazás, Effect of the radiation intensity, water turbidity and exposuretime on the survival of Cryptosporidium during simulated solar disinfection of drinking water, Acta Trop. Oct. 112 (2009) 43-48.

[17] H. Gómez-Couso, M. Fontán-Sainz, C. Navntoft, P.
Fernández-Ibáñez, E. Ares-Mazás, Comparison of different solar reactors for household disinfection of drinking water in developing countries: Evaluation of their efficacy in relation to the waterborne enteropathogen Cryptosporidium parvum, Trans. R. Soc. Trop. Med. Hyg. 106 (2013) 645-652.

[18] D.T. John, R.A. John, Mortality of mice inoculated with Giardia and cryopreserved Naegleria fowleri, Proc. Okla. Acad. Sci. 77 (1997) 35.

[19] M.R. Jamil, K. Ali Ahmad, A. Habeeb, M. Hassan, Use of solar energy for disinfection of polluted water Department of Physics, University of Agriculture, Faisalabad, Pakistan, 2009.

[20] R.J. Davies-Colley, J. Craggs, J.P. Park, J.W. Sukias, R. Nagels, Stott, Virus removal in a pilot-scale "advanced" pond system as indicated by somatic and F-RNA bacteriophages, Water Sci. Technol. 51 (2005) 107-110.

[21] W. Heaselgrave, N. Patel, S.C. Kehoe, S. Kilvington, K.G. McGuigan,: Solar disinfection of poliovirus and Acanthamoeba polyphaga cysts in water: A laboratory study using simulated sunlight, Lett. Appl. Microbiol. 43 (2006) 125-130.

[22] R. Fayer, Effect of high temperature on infectivity of Cryptosporidium parvum oocysts in water, Appl. Environ. Microbiol. 60 (1994) 2732-2735.

[23] B. Sommer, O.A. Marin, Y. Solarte, M.L. Salas, C. Dierolf, C. Valiente, et al., SODIS: An emerging water treatment process, J. Water SRT. Aqua. 46 (1997) 127-137.

[24] T. Hirata, D. Chikuma, A. Shimura, A. Hashimoto, N. Motoyama, K. Takahashi, et al., Effects of ozonation and chlorination on viability and infectivity of Cryptosporidium parvum oocysts, Water Sci. Tech. 41 (2000) 39-46.

[25] R.J. Smith, S.C. Kehoe, K.G. McGuigan, M.R. Barer, Effects of simulated solar disinfection of water on infectivity of Salmonella typhimurium, Lett. Appl. Microbiol. 31 (2000) 284-288.

[26] S.L. Hayes, E.W. Rice, M.W. Ware, F.W. Schaefer, Low pressure ultraviolet studies for inactivation of Giardia muris cysts, J. Appl. Microbiol. 94 (2003) 54-59.

[27] P.A. Rochelle, S.J. Upton, B.A. Montelone, K. Woods, The response of Cryptosporidium parvum to UV light, Trends Parasitol 21 (2005) 81-87.

[28] K.G. McGuigan, T.M. Joyce, C. Gillespie, E. Meegan, Batch solar disinfection inactivates oocysts of Cryptosporidium Parvum and cysts of Giardia muris in drinking water, J. Appl. Microbiol. 101 (1998) 453-463.

[29] M.D. Sobsey, J. Bartram, Water management: Improved water supply, World Health Organization, Water Sanitation and Health Programme, Solar disinfection of drinking water contained in transparent plastic bottles: Characterizing the bacterial inactivation process, J Appl Microbiol 84 (2004) 1138-1148.

[30] S.C. Kehoe, T.M. Joyce, P. Ibrahim, J.B. Gillespie, R.A. 
Shahar, K.G. McGuigan, Effect of agitation, turbidity, aluminium foil reflectors and container volume on the inactivation efficiency of batch-process solar disinfectors, Water Res. 35 (2001) 1061-1065.

[31] A. Martin-Dominguez, M. Alarcon-Herrera, I.R. Martin-Dominguez, A. Gonzalez-Herrera, Efficiency in the disinfection of water for human consumption in rural communities using solar radiation, Solar Energy 78 (2005) 31-40.

[32] G. Kang, M.S. Mathew, P.D. Rajan, J.D. Daniel, M.M.
Mathan, V.I. Mathan, et al., Prevalence of intestinal parasites in rural southern Indians, Trop. Med. Int. Health 3 (1998) 70-75.

[33] G.L. Mandell, J.E. Bennett, R. Dolin, Mandell, Douglas and Bennett's Principals and Practice of Infectious Diseases. Protozoal. Diseases, Vol. 2: 5th ed., Philadelphia, PA: Churchill Livingstone, 2000, pp. 450-460.

[34] World Health Organization (WHO) (2010): Household Water Treatment and Safe Storage, Vol. 5, 3rd ed., Geneva, 2010. 